\section{Microanatomical Characteristics of the Petrosphenoidal Ligament of Gruber}

\section{Gruber'in Petrosfenoidal Ligamanının Mikroanatomik Özellikleri}

\begin{abstract}
AIM: The petrosphenoidal ligament (PSL, or Gruber's ligament) is located between the petrous apex (PA) and posterior clinoid process (PCP). Details of its anatomy are conflicting in the few studies that exist in the literature. We performed this study to describe in detail the microanatomical characteristics of Gruber's ligament.
\end{abstract}

MATERIAL and METHODS: 20 human cadaveric heads (40 specimens) were used to make morphometric measurements and qualitative evaluations of the microanatomy of the petrosphenoidal ligament.

RESULTS: The anatomy of the PSL was predominately butterfly $(78 \%)$ in shape, with the remaining being triangular $(22 \%)$. The structure of the PSL was complete in $52 \%$ of cases and incomplete (fragmented or hypoplastic) in $38 \%$. A second, smaller ligament was seen in $10 \%$ of cases. Mean length of the PSL was $13.4 \pm 3.2 \mathrm{~mm}$, mean width was $6.1 \pm 3.2 \mathrm{~mm}$ at the PCP and $4.2 \pm 1.6 \mathrm{~mm}$ at the petrous apex. Butterfly-shaped ligaments were narrowest in the middle (mean $2.0 \pm 0.9 \mathrm{~mm}$ ), while triangle-shaped ligaments were narrowest (mean $2.8 \pm 2.3$ $\mathrm{mm})$ at its end, at its insertion on the PA or PCP.

CONCLUSION: The PSL (Gruber's ligament) is an important structure in the petroclival region. In this study, microanatomical characteristics were described in detail, along with new descriptions of its shape.

KEYWORDS: Petrosphenoidal ligament, Petroclival region, Skullbase

\section{ÖZ}

AMAÇ: Petrosfenoidal ligaman(PSL, veya Gruber ligamanı) petröz apeks (PA) ve posterior klinoid çıkıntı (PCP) arasında yer alır. Literatürde yer alan ilgili çalışmalarda anatomisinin detayları açık değildir. Biz bu çalışmayı Gruber ligamanının mikroanatomik özelliklerini detaylı bir şekilde tanımlayabilmek için yaptik.

YÖNTEM ve GEREÇ: 20 kadavra başı (40 örnek ) kullanarak petrosfenoidal ligamanın mikroanatomisinin morfometrik ölçümlerini yaptık ve niteliksel özelliklerini saptadık.

BULGULAR: PSL'nın anatomik olarak şekli çoğunlukla kelebek şeklinde (\%78), kalan kısmında ise üçgen şekilli (\%22) olarak saptandı. PSL'nın yapısı olguların $\% 52$ 'sinde bütün, \%38'inde bütün değildi(fragmente veya hipoplastik).İkinci bir daha küçük ligaman olguların \%10'unda görüldü.PSL'nın ortalama uzunluğu $13.4 \pm 3.2 \mathrm{~mm}$, ortalama genişliği PCP tutunma yerinde $6.1 \pm 3.2 \mathrm{~mm}$, petröz apeks tutunma yerinde $4.2 \pm 1.6 \mathrm{~mm}$ olarak bulundu. Kelebek şeklinde olanların en dar yeri ortasıyken (ortalama $2.0 \pm 0.9 \mathrm{~mm}$ ), üçgen şekillilerin en dar yeri PA veya PCP tutunma yerinde (ortalama2.8 \pm ) olabilmektedir.

SONUÇ: PSL(gruber ligamanı) petroklival bölgede önemli bir yapıdır. Bu çalışmada ligamanın mikroanatomisi detaylı bir şekilde tanımlanmış ve şekille ilgili yeni tanımlar yapılmıştır.

ANAHTAR SÖZCÜKLER: Petrosfenoidal ligaman, Peroklival bölge, Kafa tabanı

\section{Cigdem ICKE ${ }^{1}$ \\ Ercan OZER ${ }^{2}$ \\ Nuri ARDA ${ }^{3}$ \\ 1 Dokuz Eylül University, \\ Faculty of Medicine, Department of Anatomy, İzmir, Turkey \\ 2,3 Dokuz Eylül University, Department of Neurosurgery, İzmir, Turkey}

Received : 18.01.2010

Accepted : 22.03.2010

Correspondence address: Ercan OZER

Dokuz Eylül University, Faculty of Medicine, Department of Neurosurgery, Inciralti, 35340 Izmir, TURKEY Phone : +90 5056985798 Fax : +902322788802

E-mail : ercozer@yahoo.com 


\section{INTRODUCTION}

A myriad of intricate structures are found in the petroclival region, which are especially important role in procedures involving the skull base. Increased knowledge of the microanatomical features of this area has led to an increasing number of successful surgical treatments of lesions in this region. The petrosphenoidal ligament (PSL, or 'Gruber's ligament') is located between the petrous apex (PA) and posterior clinoid process (PCP), and forms the roof of Dorello's canal through which the abducens nerve passes $(3,5,6,13)$. Surgical approaches to the clivus, petroclival region, and cavernous sinus require an excellent knowledge of the microanatomy of the petroclival region $(1,5,7,13)$. Although some reports of the microanatomy of Dorello's canal also mention the PSL $(3,5,8,13)$, its microanatomical characteristics have not been clearly elucidated. In this study, we describe the microanatomical qualitative features and morphometric measurements of the PSL.

\section{MATERIALS and METHODS}

Twenty human cadaveric heads (40 specimens) were used to study the microanatomical characteristics of the PSL. After removal of the cranial vault, the encephalon was removed, and special attention was paid to the sites where the cranial nerves pierced the dura to leave the intracranial space. Microanatomical dissections were performed using a Zeiss OPMI® surgical microscope (Carl Zeiss Co., Oberkochen, Germany) in our university animal research center. In order to expose and study a PSL, the abducent nerve was followed to the site where it pierced the dura, and the PSL was then isolated by carefully dissecting away the dura. The shape and characteristics of the petrosphenoidal ligament were noted, and the following measurements were then made with calipers: the width of the PSL at the PA and PCP, the location of the narrowest section of the PSL (in the middle, at the PA end or at the PCP end), and the length between the PA and PCP. Statistical evaluations were performed using Student's t-test.

\section{RESULTS}

\section{Qualitative Observations}

The anterior end of the PSL (Gruber's ligament) is attached to the PCP and upper part of clivus, and the posterior end is attached to the petrous apex. We found the general shape of the PSL to be butterflyshaped (Figure 1A) or triangular (Figure 1B). The butterly-shaped ligaments, observed in $78 \%$ of specimens, were narrowest in the mid-section and wider at the ends where the ligament attached to the petrous apex and posterior clinoid process. The triangular PSLs, observed in $22 \%$ of cases, were widest at either the attachment to the petrous apex or the PCP. Table I lists the findings regarding the general shape of the PSL. Bilateral butterfly- or triangle-shaped Gruber's ligaments were found in $65 \%$ and $10 \%$ of the cadaveric heads, respectively. The other specimens (25\%) had one of each shaped (butterfly-shaped and triangular) PSL.

The structure of the PSL was single and complete (Figure 1A,B) in $52 \%$ of specimens and had a welldefined shape. In 15 (38\%) cases, a single PSL was incompletely formed. Of these 15 cases, it was fragmented (Figure 2A) in $13(32 \%)$ specimens and hypoplastic (Figure 2B) in $2(5 \%)$. A third form of PSL occurred in $4(10 \%)$ specimens; these had a main PSL and a smaller accessory PSL (Figure 3) present. Ossification of the PSL (Figure 3) was observed in 2 of $40(5 \%)$ specimens.

Table I: Shape (Butterly-Shaped or Triangular) of the Petrosphenoidal Ligament (Gruber's Ligament) as Examined in 20 Human Cadaveric Heads

\begin{tabular}{|l|c|c|c|}
\hline Shape & $\begin{array}{c}\text { Right } \\
\mathbf{n}(\boldsymbol{\%})\end{array}$ & $\begin{array}{c}\text { Left } \\
\mathbf{n}(\boldsymbol{\%})\end{array}$ & $\begin{array}{c}\text { Total } \\
\mathbf{n}(\%)\end{array}$ \\
\hline Butterfly-shaped (wider at the PCP) & $12(30)$ & $10(25)$ & $22(55)$ \\
\hline Butterfly-shaped (wider at the PA) & $4(10)$ & $5(12.5)$ & $9(22.5)$ \\
\hline Triangular (wider at the PCP) & $2(5)$ & $3(7.5)$ & $5(12.5)$ \\
\hline Triangular (wider at the PA) & $2(5)$ & $2(5)$ & $4(10)$ \\
\hline
\end{tabular}

PA: petrous apex, PCP: posterior clinoid process 

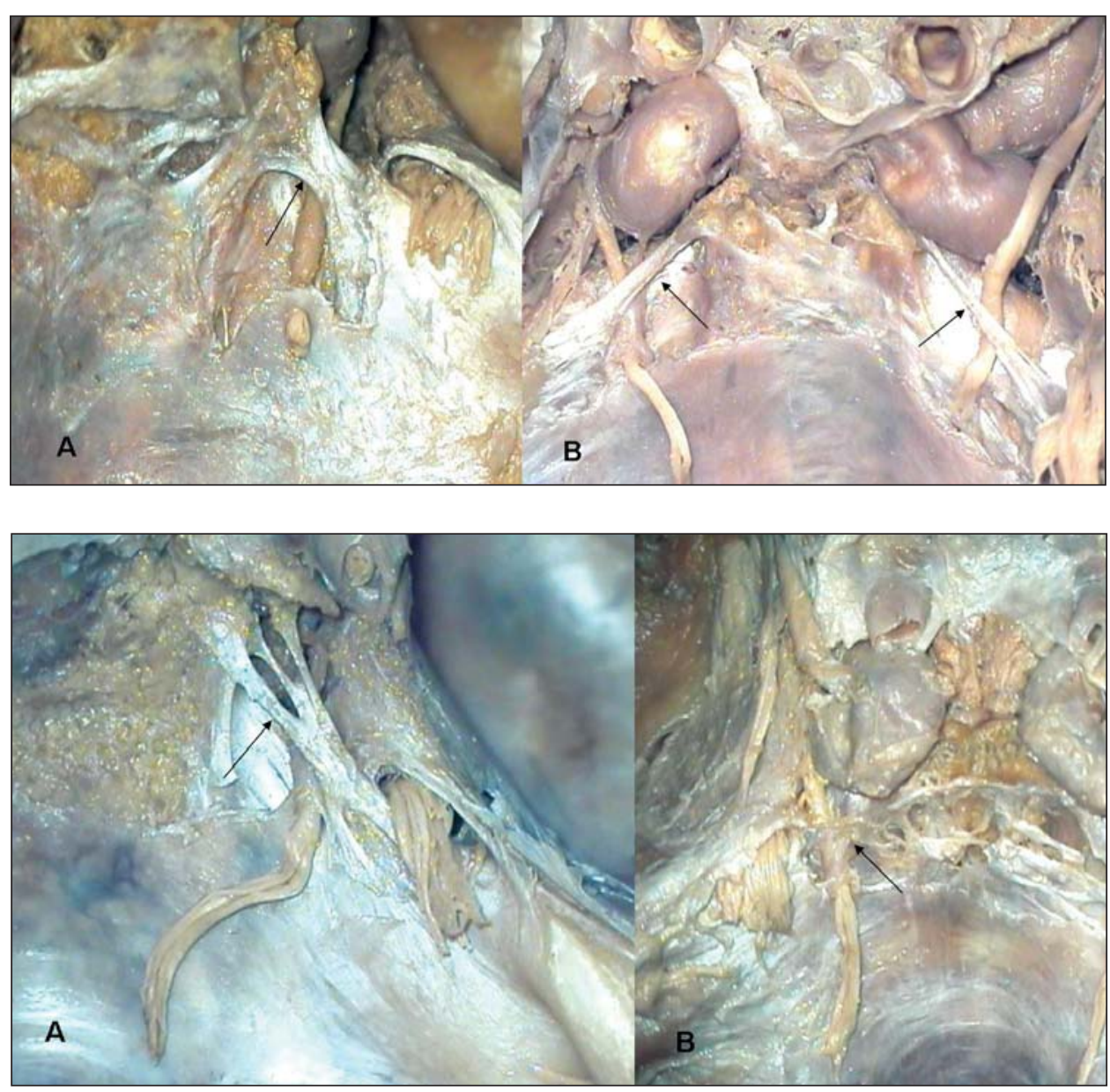

Figure 1:

(A) A petrosphenoidal ligament (Gruber's ligament) which is complete and butterfly-shaped (arrow). (B) The petrosphenoidal ligaments on both sides are complete and have a triangular shape (arrows).
Figure 2: (A) A fragmented petrosphenoidal ligament (Gruber's ligament) (arrow) and $(\boldsymbol{B})$ a rudimentary, hypoplastic petrosphenoidal ligament (Gruber's ligament) (arrow).

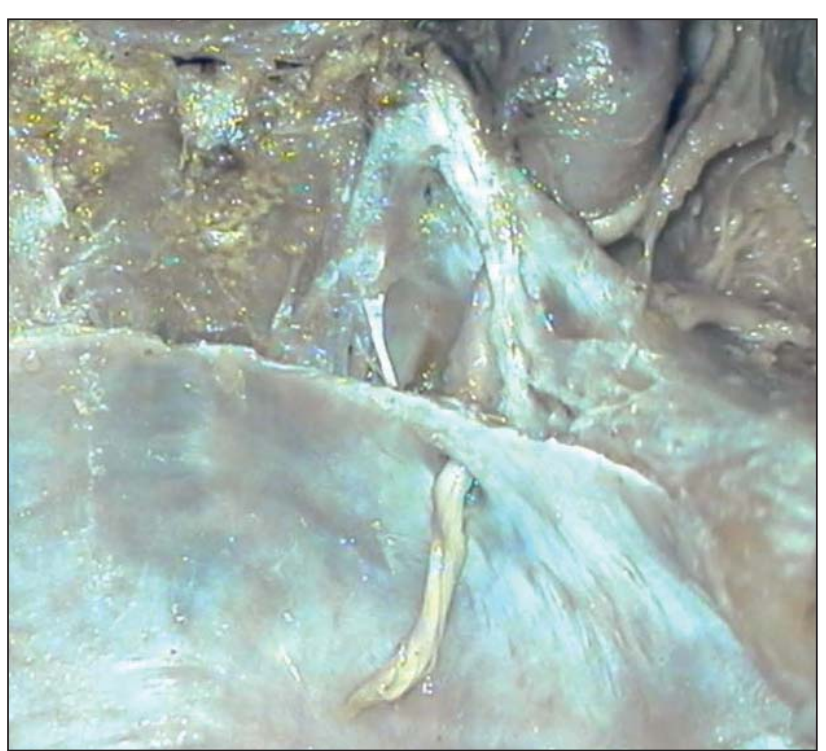

Figure 3: In this case, the main petrosphenoidal ligament (Gruber's ligament) (long arrow) is accompanied by an additional accessory ligament (short arrow).

\section{Morphometric Studies:}

The mean length of the PSL on both right and left sides was $13.4 \pm 3.3 \mathrm{~mm}$ (range 7.7-22.8 $\mathrm{mm}$ ). The mean length of the right PSL was $14.0 \pm 3.4 \mathrm{~mm}$ (range: $8.8-22.8 \mathrm{~mm}$ ) and the length of the left PSL 12.7 $\pm 3.1 \mathrm{~mm}$ (range: 7.7-21.2 $\mathrm{mm}, \mathrm{p}=0.093$ ). The mean width of the PSL was $6.1 \pm 3.2 \mathrm{~mm}$ at the posterior clinoid process and $4.2 \pm 1.6 \mathrm{~mm}$ at the petrous apex (see Table II). The mean widths of the right and left PSLs were not significantly different from each other at both attachment points $(p=0.379$ at PCP and 0.546 at Petrous Apex). Regarding the narrowest portion of the PSL, the butterfly-shaped PSLs were narrowest in their mid-sections (mean $2.0 \pm 0.9 \mathrm{~mm}$ (range: 0.9-4.6 $\mathrm{mm}$ )] whereas the narrowest portion of the triangle-shaped ligaments (at the end of attachment to the PA or PCP) measured (mean \pm SD) 2.8 $\pm 2.3 \mathrm{~mm}$ (range: 0.9-7.6 mm).

\section{DISCUSSION}

In 1859, Gruber described the presence of an osteofibrous canal at the apex of the petrous bone 
Table II: Width of the Petrosphenoidal Ligament (Gruber's Ligament) at the Petrous Apex (PA) and Posterior Dlinoid Process (PCP) as Examined in 20 Human Cadaveric Heads

\begin{tabular}{|c|c|c|c|}
\hline \multicolumn{4}{|c|}{$\begin{array}{l}\text { Width of the petrosphenoidal ligament at the } \\
\text { PCP (mm) }\end{array}$} \\
\hline & Right & Left & Total \\
\hline Mean \pm SD & $5.8 \pm 2.8$ & $6.4 \pm 3.6$ & $6.1 \pm 3.2$ \\
\hline Range & $0.9-10.2$ & $0.6-13.1$ & $0.6-13.1$ \\
\hline \multicolumn{4}{|c|}{$\begin{array}{l}\text { Width of the petrosphenoidal ligament at the } \\
\text { PA (mm) }\end{array}$} \\
\hline & Right & Left & Total \\
\hline Mean \pm SD & $4.1 \pm 1.7$ & $4.3 \pm 1.6$ & $4.2 \pm 1.6$ \\
\hline Range & $1.2-8.4$ & $1.2-8.9$ & $1.2-8.9$ \\
\hline
\end{tabular}

which he called the "foramen petro-sphenoideum". This "foramen" measured 6 to $12 \mathrm{~mm}$ in length and 1 to $3 \mathrm{~mm}$ in width and contained the abducens nerve and the inferior petrosal sinus. In most of these specimens, the posterior wall of the foramen was formed by the ligamentum petrosphenoideum or sphenopetrosum posterius (14). In the early 20th century, Gradenigo, Dorello and Vail made initial reports about the anatomy of this region (14). Because of the improvements in microanatomical technique and equipment over the last 20 years, more detailed studies of Dorello's canal and petroclival region have emerged which also mention the petrosphenoidal ligament $(3,5,6,8,13)$. However, consensus regarding its qualitative and morphometric characteristics was still lacking.

The petrosphenoidal ligament (Gruber's ligament) is an important structure in the petroclival area, not only from an anatomical point of view, but also for surgical and endovascular practice. It forms the superior portion of the falciform ligament. The inferior portion of the falciform ligament is the petrolingual ligament which covers the lacerum segment of the internal carotid artery $(8,12)$. The PSL is located at the petrovenous confluence of the superolateral part of the basilar plexus, the posterior portion of the cavernous sinus, the superior part of the inferior petrosal sinus, and the anterior part of the sphenoparietal sinus $(3,13)$. This interdural region has become a commonly used endovascular route for the treatment of carotid cavernous sinus fistulas $(2,4,10)$.
The PSL forms the roof of Dorello's canal, under which the abducens nerve passes; the petrous apex and superolateral part of the clivus form its other boundaries $(12,15)$. The abducens nerve, covered by its dural sleeve and dorsal meningeal artery, passes beneath the petrosphenoidal ligament in Dorello's canal $(5,8,11,13)$. The abducens nerve is single in majority of cases and may be duplicate in some $(6,9,12)$. The PSL inserts medially on the PCP and laterally on the petrous tubercle of the PA (5). The petrous tubercle of the PA is an optimal intraoperative landmark to use for avoiding damage to the abducens nerve while performing a subtemporal-transtentorial-transpetrous approach for the excision of posterior and middle fossa lesions. Drilling of the petrous apex, corresponding to the floor of the cavity of Meckel, should stop when the petrous tubercle comes into view intraoperatively as the abducens nerve runs just behind it $(5,6)$.

The PSL is butterly-shaped in most and triangleshaped in some. Iaconetta et al. (5), Özveren et al. (13) and Liu et al. (8) described it as being only butterfly-shaped. We agree with Destrieux et al. (3), who described it as being butterfly-shaped or triangular. We also found, as did Destrieux et al., that the width of the PSL of Gruber (in both butterflyand triangle-shaped groups) was widest at the end inserting on the PCP in most cases. On the contrary, Iaconetta et al. (5) and Liu et al. (8) found the width of the PSL to be larger at the PA end of the ligament. We found the narrowest portion of the butterflyshaped ligaments (mean $\pm \mathrm{SD}=2.0 \pm 0.9 \mathrm{~mm}$ ) to be in the middle section, which corresponded with the findings $(2.0 \pm 1.8 \mathrm{~mm})$ of Iaconetta et al (5). The mean width at the midpoint of the PSL in the specimens examined by Liu et al. was a bit greater, $2.6 \pm 0.9 \mathrm{~mm}$ (8).

The PSL can be described as either complete or incomplete, with incomplete ligaments being fragmented or hypoplastic. In some cases, an additional smaller ligament accompanies the main PSL ligament. Among these variations, only hypoplastic PSL ligaments had been mentioned in the literature; occuring in $10 \%$ in the study by Liu et al. (8) and 3\% in the study by Iaconetta et al. (5), which is similar to the prevalence $(5 \%)$ in our study. Destrieux et al. (3) defined the hypoplastic PSL as very thin or translucent. The present study is the first to classify Gruber's ligaments structurally, as 
"complete", "incomplete" (with its subtype "fragmented", in addition to the previously used "hypoplastic"), and "accessory ligament of the main PSL".

We found the length of the PSL to be $13.4 \pm 3.2$ $\mathrm{mm}$, which is similar to that $(13.3 \pm 2.3 \mathrm{~mm})$ reported by Iaconetta et al. (5) and Liu et al. (13.9 $\pm 2.7 \mathrm{~mm}$ and $13.2 \pm 2.2 \mathrm{~mm}$ at its medial and lateral insertions respectively) (8), but longer than that $(10.3 \mathrm{~mm})$ reported by Özveren et al. (13). The lengths of the right and left PSLs were similar in our specimens.

The PSL may sometimes calcify and form a bony canal (9), which occurred in 5\% of our specimens, and is reported to occur in 3-6\% $(3,5)$. In one report (12) of a bony canal in which the abducens nerve passed below the petrooccipital suture, the authors suggested that this occurred during embryological development, but a more likely explanation for the formation of the bony canal was calcification of the PSL (14).

The main function of the PSL is reported to be fixation of the sheath of the abducens nerve in the petroclival venous confluence (3). The abducens nerve is also protected by the petrosphenoidal ligament during petrous bone drilling which occurs during the anterior petrosal approach (13). ). In case of duplication of the abducens nerve, one of the branches is fixed separately in half of the duplicated cases (12), and one of the branches may pass over the PSL; these possible variants must be taken into account when performing surgery in this region $(8,12)$.

Gruber's ligament, the petrosphenoidal ligament, is a very important structure in the petrosphenoclival region. It can be triangular or butterfly-shaped, and structurally intact, fragmented, hypoplastic or accompanied by an additional accessory ligament. Exact knowledge of the microanatomical characteristics of PSL may help the operator when performing surgical procedures in this region.

\section{ACKNOWLEDGEMENTS}

The authors would like to thank Dr. Türkan Günay who helped with the statistical calculations for the study.

\section{REFERENCES}

1. Alkan A, Sıgırcı A, Özveren MF, Kutlu R, Altınok T, Onal Ç, Sarac K: The cisternal segment of the abducens nerve in man: Three dimensional MR imaging. Eur J Radiol 51:218-222; 2004

2. Barnwell SL, O'Neil OR: Endovascular therapy of cavernous sinus fistulas. Neurosurg Clin N Am 5:485-495, 1994

3. Destrieux C, Velut S, Kakou MK, Lefranck T, Arbeille B, Santini JJ: A new concept in Dorello's canal microanatomy: Petroclival venous confluence. J Neurosurg 87:67-72, 1997

4. Halbach VV, Higashida RT, Hieshima GB, Hardin CW, Yang PJ: Transvenous embolization of direct carotid cavernous fistulas. AJNR Am J Neuroradiol 9:741-747, 1988

5. Iaconetta G, Fusco M, Cavallo LM, Cappabianca P, Samii M, Tschabitscher M: The abducens nerve: Microanatomic and endoscopic study. Neurosurgery 61(3 Suppl):7-14, 2007

6. Iaconetta G, Tessitore E, Samii M: Duplicated abducent nerve and its course: Microanatomical study and surgery related considerations. J Neurosurg 95:853-858, 2001

7. Knopp U, Kleedehn M, Kühnel W, Sepehrnia A: Mikroanatomie des Sinus cavernosus. Ann Anat 187:127-134; 2005

8. Liu X, Xu Q, Che X, Mao R: Anatomy of the petrosphenoidal and petrolingual ligaments at the petrous apex. Clin Anat 22:302-306, 2009

9. Nathan H, Quaknine G, Kosary IZ: The abducens nerve: Anatomical variations in its course. J Neurosurg 41:561-566, 1974

10. Oishi H, Arai H, Sato K, Iuzuka Y: Complications of transvenous embolization of cavernous dural arteriovenous fistula. Acta Neurochir (Wien)141:1265-1271, 1999

11. Ono K, Arai H, Endo T, Tsunoda A, Sato K, Sakai T, Makita J: Detailed MR imaging anatomy of the abducent nerve: Evagination of CSF into Dorello canal. AJNR Am J Neuroradiol 25:623-626, 2004

12. Özveren MF, Sam B, Akdemir I, Alkan A, Tekdemir I, Deda H: Duplication of the abducent nerve at the petroclival region: An anatomic study. Neurosurgery 52:645-652, 2003

13. Özveren MF, Uchida K, Aiso S, Kawase T: Meningovenous structures of the petroclival region: Clinical importance for surgery and intravascular surgery. Neurosurgery 50:829-836, 2002

14. Umansky F, Elidan J, Rezo AVA: Dorello's canal: A microanatomical study. J Neurosurg 75:294-298; 1991

15. Umansky F, Valarezo A, Elidan J: The microsurgical anatomy of the abducens nerve in its intracranial course. Laryngoscope 102:1285-1292, 1992 